\title{
Regulation of Private Land Banking During the Agrarian Reform in Indonesia
}

\author{
Erni Herawati ${ }^{1^{*}}$, A S Hutagalung ${ }^{2}, \mathrm{~S}$ Sujadi $^{2}$ and R Lestarini ${ }^{2}$ \\ ${ }^{1}$ Business Law Program, Law Department, Faculty of Humanities, Bina Nusantara University, Jakarta, \\ Indonesia 11480 \\ ${ }^{2}$ Law Faculty, Universitas Indonesia, Jakarta, Indonesia \\ *Corresponding author email: erni-herawati@binus.ac.id
}

\begin{abstract}
The land banking institution is one of the provisions stipulated in the Job Creation Law that must be implemented by the government. Meanwhile, it is known that land banking is one of the business strategies by the private sector. On the other hand, there is no provision for the maximum amount of land ownership by individuals or legal entities, which is why the private sector can control a large amount of land. The problem in this research is whether the agrarian reform program has regulated the maximum acquisition of land area by the private sector and whether it is in line with the sustainable development goal. The results showed that Job Creation Law supports the ease of investment in Indonesia but does not concern about land banking activities by the private sectors. The process of location permits for land acquiring for investment purposes has been made easier. Another fact shows that land controlled activities by public companies continued to show an increase even during the Covid-19 Pandemic outbreak.
\end{abstract}

Keywords: Regulation, Land Banking, Agrarian, Indonesia

\section{INTRODUCTION}

On November 2, 2020, the Government has signed Law Number 11 of 2020 on Job Creation, popularly known as Omnibus Law. As mentioned in consideration of Job Creation Law, the provisions regarding the ease of doing business are expected to be able to create new jobs and workforce as well. The purpose of the enactment of the Job Creation Law is to cut the existing bureaucratic process and hope that it will have an impact on the acceleration of public services. It predicted that the acceleration of business permit services would affect the Ease of Doing Business (EoDB) index in Indonesia and will help the process of national economic recovery after the Covid-19 pandemic [1]. According to World Bank data, the EoDB index in Indonesia as of September 2020 shows that Indonesia is in the $73^{\text {rd }}$ position out of 190 countries. However, the ranking has been stagnant over the past two years [1].

Regulations regarding the ease of investment permit in the Job Creation Law are expected to have an impact on the growth of new investments. Almost all investments require land as a place to run their business. For the purposes of land acquisition and transfer of land rights for investment plans, investors are required to have a location permit that functions as a land acquisition permit and the requested location must be in accordance with the spatial planning. One of the subjects regulated in the location permit is the limitation of the investor for acquiring the land area for investment purposes. Apart from plantations and agriculture, the property business is a field that requires a large area of land. Data shows that in 1995 in Jakarta, Bogor, Tangerang, Bekasi (Jabotabek), there were developer company groups such as Metropolitan (Pondok Indah), Bumi Serpong Damai, Pembangunan Jaya, Lippo and Summarecon which had controlled more than 4,000 hectares of land [2]. These companies are still developing their businesses with a total market capitalization of trillions of rupiah. The land banking strategies of these companies began in the 1990s. Starting from the era of the New Order government which opened up investment opportunities on a large scale to overcome the economic crisis left by the Old Order government. These facts show that there are no regulations regarding restrictions on land ownership by companies. This is in stark contrast to the agrarian reform program (land reform) that has been implemented since the Basic Agrarian Law (BAL) was enacted in 1960.

The contradiction between the implementation of the land reform program and the wide access to land ownership for investors provided by the government often leaves gaps in achieving sustainable community welfare. One example is the high land prices will lead to high affordable housing prices for 
people with low income. Therefore, this study are questioning about how the agrarian reform program has regulated the maximum acquisition of land tenure for the private sector and also whether it is in line with the concept of sustainable development? to answere these question, this study using qualitative approach with literature review. The data in this study was also obtained by direct interview to two officials at the Ministry of Agrarian Affairs and Spatial Planning / BPN who are authorized to handle location permits. ${ }^{1}$ Interviews were conducted using interview guidelines with open questions.

\section{LITERATURE REVIEW}

\subsection{Agrarian reform}

Agrarian reform is often referred to as land reform. Land reform is an effort to distribute land to smallholders to own land. This is done as an effort to prevent the concentration of land ownership by a few people. This effort is quite popular among countries in Asia, Africa, and Latin America in an effort to advance their economies [3]. Indonesia's agrarian reform has begun since the Old Order government, after the BAL was enacted. Based on Article 17 of BAL concerning the determination of the area of agricultural land therefore the Government Regulation no. 224 of 1961 was stipulated. The regulation regulates the implementation of land reform in Indonesia, but this provision only regulates ownership of agricultural land by individual farmers or collectively as family farmers with a maximum control or ownership of agricultural land of 20 hectares. The total area of land controlled by legal entities is exempted. The restrictions on land tenure for non-agricultural businesses have also not become a concern. The land reform program at the end of the Old Order government era could no longer be implemented as intended because of the sociopolitical situation [4].

The land redistribution program was opposed by the land owner and the land that had been distributed was taken back by the owner, and the compensation provided was deemed inappropriate. [4] During the New Order era, the Government did not continue the land reform program because this program was considered to be an obstacle to economic development efforts that were to be achieved in a short time [5]. Therefore, during the New Order era, there was massive land control by investors. The allocation of land use during the New Order era was focused on the interests of economic growth by opening the widest possible access for capital owners to control people's lands [5]. Government policies have shifted from land policies from populist to pro-capital characteristics due to the choice of economic policy orientation [6]. The approach taken by the New Order government tended to be capitalist, therefore land was only seen as a commodity. This pro-investment orientation can be seen in the regulations promulgated by the New Order government since the enactment of Law no. 1 of 1967 on Foreign Investment (PMA) and Law no. 8 of 1968 on Domestic Investment (PMDN). Application for land rights for investment purposes, both PMA and PMDN, were then more privileged through the October 1993 Deregulation Package policy.

During the reform period, The Indonesian People's Consultative Assembly (MPR) issued decree No. IX / MPR / 2001 concerning Agrarian Reform and Natural Resource Management. Article 2 jo. Article 5 paragraph (1) letter b explicitly regulates the President's mandate to restructure the control, ownership, use and utilization of agrarian resources including land. Reorganization of the use, ownership, use and utilization of land is carried out through land reform by taking into account land ownership for the community to achieve justice. In the 2005-2025 Long Term Development Plan, land reform is carried out in order to achieve a more equitable development. Post-reform, both the Government of President Soesilo Bambang Yudhoyono and President Joko Widodo made land reform as one of their policies in the land sector, but until now the implementation of land reform policy is still limited to land certification.

\subsection{Location Permit Regulation}

The era of investment liberalization was marked by the promulgation of the PMA Law and the PMDN Law. In both laws, the private sector is given the freedom to carry out economic and business activities in almost all fields. The private sector is positioned as the engine of economic growth [7]. The focus of land policy was more on efforts to support rapid economic growth. Applications for land rights for investment purposes, both PMA and PMDN, have special rights where the government gives location permits to investor and then they can carry out land acquisition by themselves [5]. Foreign investors who need land can directly submit their application to the Investment Coordinating Board (BKPM). By the approval of the President which 
also applies as a Principle License, companies can directly apply for a Location Permit to the local Regency/City Land Office [8], whereas at that time the government's authority in the land sector had not been decentralized.

The government provides rules regarding private ownership and land control, but in each of these regulations there is always an exception clause where the private party can acquire land beyond the maximum provision. In the Regulation of the State Minister for Agrarian Affairs / BPN No. 14 of 2018 on location permits Article 5 paragraph (1) (2) states maximum land controlled by a company below:

TABLE 1. Maximum land controlled by a company

\begin{tabular}{|l|l|l|}
\hline Business & $\begin{array}{l}\text { Total area in in } \\
\text { a Province }\end{array}$ & $\begin{array}{l}\text { Indonesia } \\
\text { Indea in }\end{array}$ \\
\hline $\begin{array}{l}\text { Housing and } \\
\text { settlement }\end{array}$ & $400 \mathrm{Ha}$ & $4.000 \mathrm{Ha}$ \\
\hline Hospitality & $200 \mathrm{Ha}$ & $4.000 \mathrm{Ha}$ \\
\hline $\begin{array}{l}\text { Specific economic } \\
\text { area }\end{array}$ & $400 \mathrm{Ha}$ & $4.000 \mathrm{Ha}$ \\
\hline $\begin{array}{l}\text { Plantation } \\
\text { - Sugar cane } \\
\text { - Others }\end{array}$ & $60.000 \mathrm{Ha}$ & $150.000 \mathrm{Ha}$ \\
\hline $\begin{array}{l}\text { Fishpond } \\
-\quad \text { Java island } \\
-\quad \text { Outside Java } \\
\text { island }\end{array}$ & $100 \mathrm{Ha}$ & $100.000 \mathrm{Ha}$ \\
\hline \multicolumn{2}{|l|}{$2000 \mathrm{Ha}$} & $2.000 \mathrm{Ha}$ \\
\hline
\end{tabular}

Apart from the list of land tenures that can be controlled by companies as listed in the table above, for Papua province the number of land tenure is twice the provisions stipulated for one province. Article 5 Paragraph (4) stipulate the exception clause of previous paragraph, it state that the maximum land controlled are exclude for state or regional-own enterprises and public companies.

\subsection{Land Banking}

The legal terminology of land bank is known after the enactment of Law Number 11 of 2020 on Job Creation. According to Sumardjono, land bank has a characteristic as a public institution, namely a land bank as an activity carried out by the Government [9]. According to the dictionary of the National Land Agency (BPN), a land bank is an institution that obtains urban land or land to assist in the management (provision and control of land or land use) of urban space as planned [10]. The function of the land bank are as a land keeper or land reserve, a land security for various development needs in the future (land warantee), a land purchaser and as land distribution for various development needs (land distributor) [11].

There are two types of land banks, namely public land banks and private land banks [11]. A public land bank is a land bank run by a public institution and a private land bank run by a private party. Public land banks are known after being regulated in Article 125-135 Job Creation Law and will be formed later. One of the lands that will be managed by this institution will come from land left by investors. In fact, private land banks have long been run by investors mainly by companies engaged in property or real estate. The main motive of private companies conducting this land bank is to remain profitable, and the availability of land in the long term is expected to increase the value or land speculation [11].

\section{DISCUSSION}

One of the founding fathers of the nation, Hatta, said that land should not be used as a tool to oppress other groups because it is against the basis of a just economy as aspired by the Indonesian people [5]. Thus, land must not become a commodity that can be traded for profit without any restrictions, because if there is concentration of land ownership in a group of people, then there will be oppression of the weak people. Therefore, the state power is needed in determining the allocation of land use and ownership [5]. Article 7 BAL which prohibits ownership and control over land that exceeds the limit and Article 11 paragraph (1) BAL stipulates that the legal relationship between legal subjects and natural resources will be regulated, therefore the control over life and work by others can be prevented from exceeding the limit.

The government is the party that has the authority to regulate the distribution of land use in Indonesia based on the Rights of the State as regulated in Article 2 paragraph (2) of the BAL. However, until now the ownership and control of land by the private sector as well as land for non-agricultural purposes has not been realized. Location permit is one part of control means at the national to district levels. However, regulations regarding location permits have not provided a limit to the area of land owned by companies in acquiring land for their businesses. The National Land Agency as an institution that has authority in the land sector has not developed a database that can detect the total area of land owned by companies. Each applicant for a location permit can apply for a license to provide land for his business, without any mechanism from the government to check whether the land controlled by 
the company has exceeded the limit stipulated in the location permit provisions or not [12]. With this system, the company has a great opportunity to reserve as much land areas as desired. By holding this license, company has the opportunity to acquire large land area and then determine the highest price for the property they sell. One of the impact of high land prices is the difficulty for people to buy houses at affordable prices. The phenomenon of high prices of house due to high land prices is a similar problem in China [13]. Li, Wong, and Cheung in their research in Hong Kong stated that the land economy is a problem that requires government intervention, because it affects the high prices of the house for the people [14].

In the data presented in the intoduction above, it is mentioned that land reserves have been carried out since the 1990s when the New Order Government provided various investment facilities for entrepreneurs. Referring to the data from the Indonesia Stock Exchange in 2019, currently there are five companies that have assets of trillions of rupiah and have land banking, namely PT. Lippo Karawaci Tbk, PT. Bumi Serpong Damai Tbk, PT. Ciputra Develompment Tbk, PT. Agung Podomoro Land Tbk, and PT. Pakuwon Jati Tbk [15]. All of these companies are public companies. Based on the rules of location permits, as public companies, they allowed to control land area without limitation. This data confirms that the provisions on land tenure and ownership for the non-agricultural private sector should also be a concern. This is in line with the objective of the land reform program, which is to remove the concentration of land ownership on a large scale for a few people. The enactment of the Job Creation Law only regulates land banks as public institutions that are expected to be able to control land prices which are increasingly unaffordable for the community, while one of the causes of uncontrolled land prices is not being considered. The unavailability of provisions regarding the limitation on the control and ownership of land by the private sector and the omission of companies that do not immediately cultivate the land under their control has led to speculation which has resulted in high land prices. Even amid the decline of people's purchasing ability during the Covid-19 pandemic to buy property, PT Ciputra Development Tbk continues to purchase land in the Jabodetabek and Surabaya areas to increase their land banking [16]. The high price of land makes it difficult for people to get access to support their welfare, such as meeting the needs of a decent house.

\section{CONCLUSION}

The Indonesian government has enacted the Job Creation Law to support the ease of investing in Indonesia. Provisions regarding investment facilities are not only carried out by the current government, but have been carried out by the government during the New Order era. However, this facility for ease of investment does not concern to the limits on land ownership that can be controlled by the companies, therefore the companies has been doing land banking for a long time and has been running until now. This land banking activity continues during the current Covid 19 pandemic. Large companies' access to land causes land prices to soar and creates land that is difficult for low-income people to reach. The Job Creation Law only stipulates the land banking issues for the establishment of land banking as public institution. Therefore, these provisions that do not support the creation of justice for society need to be reviewed by the government, because it are not in accordance with the goals of sustainable development. Inequitable access to land can affect injustice to the welfare of the people. Therefore, government intervention in controlling high land prices can be started by controlling land ownership by companies.

\section{REFERENCES}

[1] Humas Menpan "UU Cipta Kerja Tingkatkan Kemudahan Berusaha dan Kualitas Pelayanan Publik" (On-Line) https://www.menpan.go.id/site/beritaterkini/uu-cipta-kerja-tingkatkankemudahan-berusaha-dan-kualitaspelayanan-publik, retrieved November, 5 2020

[2] Anonim "Dari Ulang Tahun Ke-23 REI: Menggugat Hak Atas Penguasaan Tanah" Kompas 27-03-1995.

[3] Andi A Tanah bagi yang Tak Bertanah: Landreform pada Masa Demokrasi Terpimpin 1960-1965 (Bogor: Kekal Pers)

[4] Hutagalung A S 1985 Program Redistribusi Tanah di Indonesia: Suatu Sarana ke Arah Pemecahan Masalah Penguasaan Tanah dan Pemilikan Tanah (Jakarta: Penerbit CV Rajawali)

[5] Suhendar E and Kasim I 1996 Tanah Sebagai Komoditas (Lembaga Studi dan Advokasi Masyarakat (ELSAM)

[6] Sumardjono M S W 2008 "Tanah dalam Perspektif Hak Ekonomi Sosial dan Budaya" (Jakarta: PT. Kompas Media Nusantara, 2008) 
[7] Rahardjo D 1997 "Demokrasi Ekonomi dalam Alam Liberalisasi Ekonomi" in Kumala $\mathrm{H}$ et all (eds) Agenda Aksi Liberalisasi Ekonomi dan Politik di Indonesia (Yogyakarta: PT. Tiara Wacana Yogya, 1997)

[8] Jened R 2016 Teori dan Kebijakan Hukum Investasi Langsung (Direct Investment) (Jakarta: Kencana)

[9] Sumardjono M S W 2005 Kebijakan Pertanahan: Antara Regulasi dan Implementasi (Jakarta: Buku Kompas)

[10] Kementerian Agraria dan Tata Ruang/Badan Pertanahan Nasional 2017 Kamus Agraria dan Tata Ruang (Jakarta: Percetakan Pohon Cahaya)

[11] Mochtar H 2013 Keberadaan Bank Tanah dalam Pengadaan Tanah untuk Pembangunan Jurnal Cakrawala Hukum Vol.18 No.2 pp 127-135

[12] Anonim 19-08-2020 Interview with official at National Land Agency

[13] Xu Y and Zhou Y 2017 Relationship Between Housing Price and Land Price Based on Grey Relational Analysis Agricultural Science \& Technology 18(5) pp 880-883

[14] Li L H, Wong S.K and Cheung, K S. 2016 Land supply and housing prices in Hong Kong: The political economy of urban land policy Environ. Plan. C Gov. Policy 34 pp 981-998.

[15] Mutiara N Bisnis.com, "Siapakah Raja Properti di Tanah Air?. https://ekonomi.bisnis.com/read/20200128/4 7/1194516/siapakah-raja-properti-di-tanahair

[16] Hilda B A Kompas.com. "Saat Pandemi, Pengembang Properti Fokus Belanja Lahan", https://properti.kompas.com/read/2020/04/2 8/150804421/saat-pandemi-pengembangproperti-fokus-belanja-lahan?page=all 